\section{REDIMAT}

Journal of Research in Mathematics Education
Hipatia Press

www.hipatiapress.com

Instructions for authors, subscriptions and further details:

http://redimat.hipatiapress.com

\title{
List of Reviewers
}

Date of publication: February $24^{\text {th }}, 2018$

Edition period: February 2018-June 2018

To cite this list of reviewers: (2016). List of Reviewers. REDIMAT, 7(1), 107. doi: 10.17583/redimat.2018.3325

To link this article: http://dx.doi.org/10.17583/redimat.2018.3325

\section{PLEASE SCROLL DOWN FOR ARTICLE}

The terms and conditions of use are related to the Open Journal System and to Creative Commons Attribution License (CC-BY). 


\section{List of Reviewers}

On behalf of REDIMAT we deeply appreciate contributions provided by the reviewers to the quality of this journal, during 2017. The journal owes this debt with those who have been peer reviewers during this period. Yours sincerely,

Javier Díez-Palomar Chief Editor

Salvador Vidal Secretary

Berta Barquero

Marcelo Bairral Associated Editors

Adriana Aubert

Aitor Gómez

Ana Corica

Anna Chronaki

Anthony Fernandes

Assumpta Estrada

Benedetto Di Paola

Berta Barquero

Carmen López Esteban

Itxaso Tellado
José Cortés Zavala

José Gutiérrez

Liviu Mara

Luis Pino-Fan

Marta Capllonch

Olga Serradell

Pilar Álvarez

Roger Campdepadrós

Silvia Molina

Vicenç Font

William Zahner 